\title{
Modelling of historical tsunami in Eastern Indonesia: 1674 Ambon and 1992 Flores case studies
}

Ignatius Ryan Pranantyo, Phil Cummins, Jonathan Griffin, Gareth Davies, and Hamzah Latief

Citation: AIP Conference Proceedings 1857, 090005 (2017); doi: 10.1063/1.4987104

View online: http://dx.doi.org/10.1063/1.4987104

View Table of Contents: http://aip.scitation.org/toc/apc/1857/1

Published by the American Institute of Physics 


\title{
Modelling of historical tsunami in eastern Indonesia: 1674 Ambon and 1992 Flores case studies
}

\author{
Ignatius Ryan Pranantyo ${ }^{1, a)}$, Phil Cummins ${ }^{1}$, Jonathan Griffin², Gareth Davies², \\ Hamzah Latief ${ }^{3}$ \\ ${ }^{1}$ Research School of Earth Sciences, the Australian National University, Australia \\ ${ }^{2}$ Geoscience Australia, Australia \\ ${ }^{3}$ Oceanography Department, Institute Technology of Bandung, Indonesia
}

a)Corresponding author: ryan.pranantyo@anu.edu.au

\begin{abstract}
In order to reliably assess tsunami hazard in eastern Indonesia, we need to understand how historical events were generated. Here we consider two such events: the 1674 Ambon and the 1992 Flores tsunamis. Firstly, Ambon Island suffered a devastating earthquake that generated a tsunami with $100 \mathrm{~m}$ run-up height on the north coast of the island in 1674. However, there is no known active fault around the island capable of generating such a gigantic wave. Rumphius' report describes that the initial wave was coming from three villages that collapsed immediately after the earthquake with width as far as a musket shot. Moreover, a very high tsunami was only observed locally. We suspect that a submarine landslide was the main cause of the gigantic tsunami on the north side of Ambon Island. Unfortunately, there is no data available to confirm if landslide have occurred in this region. Secondly, several tsunami source models for the 1992 Flores event have been suggested. However, the fault strike is quite different compare to the existing Flores back-arc thrust and has not been well validated against a tide gauge waveform at Palopo, Sulawesi. We considered a tsunami model based on Griffin, et al., 2015, extended with high resolution bathymetry laround Palopo, in order to validate the latest tsunami source model available. In general, the model produces a good agreement with tsunami waveforms, but arrives 10 minutes late compared to observed data. In addition, the source overestimates the tsunami inundation west of Maumere, and does not account for the presumed landslide tsunami on the east side of Flores Island.
\end{abstract}

\section{INTRODUCTION}

Eastern Indonesia is well known as one of the most complex tectonic regions in the world and has high seismicity. One factor that should be considered for those living in such as tectonically active zone is tsunami as a coastal hazard. As the population and economy are growing over time in this region a comprehensive tsunami hazard assessment is needed. One key step of this activity is understanding historical tsunami events in this region. Unfortunately, detailed historical information for each event is limited. Existing tsunami catalogues mostly just mention that a region was affected by a tsunami but without complete information on where and how the wave was generated. Therefore, understanding how historical events were generated is a crucial and the first step for assessing tsunami hazard in this region.

Despite the limited information, a few written historical events provide some detailed information. This information can be used to do tsunami source reconstruction in order to answer how and where the tsunami was generated. Here we consider the 1674 Ambon and 1992 Flores tsunamis. The first event is chosen as a historical event for which no instrumental data was recorded but which had a detailed written report. The second one represents the first modern tsunami in Indonesia where instrumental equipment recorded seismic and tide gauge waveforms, and for which there exist accurate tsunami height measurement from a post-tsunami field survey.

International Symposium on Earth Hazard and Disaster Mitigation (ISEDM) 2016

AIP Conf. Proc. 1857, 090005-1-090005-7; doi: 10.1063/1.4987104

Published by AIP Publishing. 978-0-7354-1531-7/\$30.00 


\section{THE 1674 AMBON TSUNAMI}

According to [1] on 17 February 1674 Ambon Island suffered a devastating earthquake. A strong earthquake was felt at Hitu and Leitimor. Then it was followed by a gigantic tsunami with up to $100 \mathrm{~m}$ run-up on the, northern coast of Ambon Island, while the rest of the area just experienced minor tsunami. The event occurred during the Chinese New Year celebration and took more than 2000 victims, mostly from the north coast of the island [1]. Tsunami catalogues available [2], [3], [4] suggested that this event was mainly caused by an earthquake. We still do not know where the wave was exactly coming from. As a blind man, [1] succeed in collecting tsunami information from the entire Island. Based on this limited information, we try to answer how and where the tsunami was generated.

We reconstruct the tsunami source by conducting tsunami modelling by solving a nonlinear shallow water wave equation using the JAGURS code [5]. We digitized nautical charts then combined with the TCarta Marine dataset and the General Bathymetric Chart of the Oceans (GEBCO) as an input for the model. We use Shuttle Radar Topography Mission (SRTM), as no high resolution topography model is available. Then we run five scenarios in order to find the most plausible tsunami source of this event (Table 1). Three scenarios represent tsunamigenic earthquake models, while the other represents a tsunami induced by a landslide.

Scenario F01 represents north Seram megathrust earthquake with magnitude Mw 8.0 (Fig 1a). As a megathrust event, firstly we assume it might generate high tsunami wave on the north coast of Ambon Island with minor tsunamis surround the island. On the other hand, this scenario just produces less than $0.5 \mathrm{~m}$ tsunami height along the north coast of Ambon with up to $5.5 \mathrm{~m}$ tsunami on the northwest of Seram (Fig 1a). Moreover, the tsunami generated by this scenario is much lower than the tsunami height reported.

In 1950, Ambon Bay was hit by high tsunami generated by a M 7.3 earthquake with epicenter south of the island. We use this event as scenario F02 (Fig 1b) and assume the 1674 event was from the same source zone. This scenario generates a high tsunami at Ambon Bay, Haruku, and Saparua Straits. However, just a minor tsunami on the north coast of Ambon Island resulted (Fig 1b).

A recent study suggested a normal fault onshore of northern coast of Ambon dipping to Piru Bay [6]. It matches with [7] which mentions five local tectonic faults associated with an earthquake in 1898, one of which has a vertical component on the north coast of the island. Based on a scaling law [8] it might generate up to a Mw 6.5 earthquake. Therefore, we run this possibility as scenario F03 (Fig 1c). This scenario produces tsunami height up to $2 \mathrm{~m}$ on the northern coast of Ambon Island and at Piru Bay with minor tsunamis at Ambon Bay, Haruku, and Saparua. However, it does not produce a tsunami as high as reported [1] on the northern side of Ambon Island.

[1] mentions that three villages on the north coast of the island collapsed with width as far as a musket shot $(\sim 200$ m) immediately after the earthquake. Furthermore, Nusatello Island reported that the high wave was coming from three collapsed villages and the wave spread out into three directions, to Nusatello, Piru Bay, and eastern Hila. Moreover, a very high tsunami was observed at this region. These villages are located at the same place as the normal fault suggested at F03 scenario. A normal fault mechanism may trigger a landslide. Therefore, we consider a tsunami landslide as a possibility of the 1674 Ambon event.

As no detailed landslide information is available, we assume the landslide mass movement has a Gaussian shape following [9]. Then we assume scenario L01 represents a subaerial landslide with $10 \mathrm{~km}$ length and $200 \mathrm{~m}$ width (as far as a musket shot). Moreover, we assume the thickness of the landslide is $100 \mathrm{~m}$ and that it started to slide from depth $150 \mathrm{~m}$. Then we use $15^{\circ}$ slope as an average steepness on the bathymetry offshore of northern Ambon Island. Then we generate an initial sea surface displacement with these parameters using [9] empirical kinematic equation (Fig 1d). This scenario produces a high tsunami of up to $15 \mathrm{~m}$ on the north coast of Ambon Island and Piru Bay. Moreover, minor tsunamis on the rest of the area match well to [1]. However, this scenario does not generate a tsunami up to $100 \mathrm{~m}$.

Then we consider a smaller submarine landslide (scenario L02) on this region with $5 \mathrm{~km}$ length, $200 \mathrm{~m}$ width, 200 $\mathrm{m}$ thickness, and the slide started at depth $350 \mathrm{~m}$. This scenario produces a similar tsunami height pattern compare to scenario L01 but with smaller tsunami maximum height (Fig 1e).

From these five scenarios, we suggest tsunami landslide induced by earthquake or a normal fault onshore of northern part of Ambon Island was the most plausible tsunami source of the 1674 event. However, neither detailed landslide evidence nor tectonic information are available on this region. 
TABLE 1. Five scenarios of the 1674 Ambon tsunami

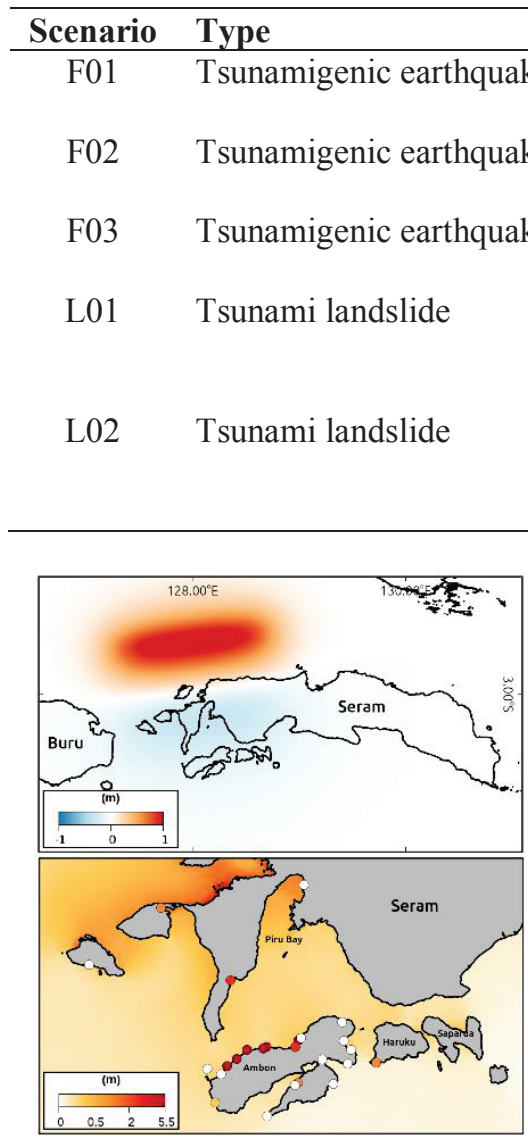

(a)

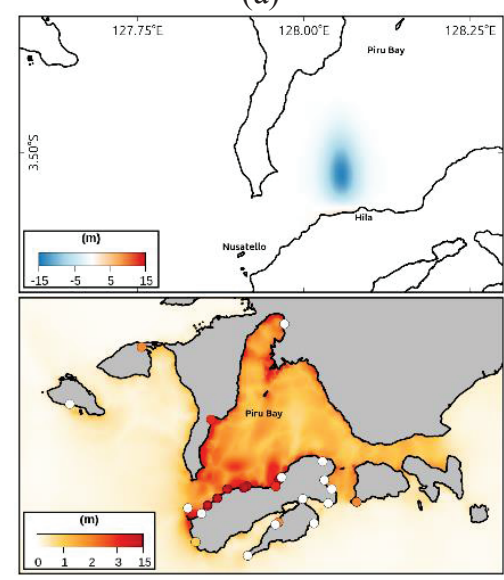

(d)

\section{Parameters}

Mw 8.0, $165 \mathrm{~km}^{*} 70 \mathrm{~km}$

Dip $20^{\circ}$, Depth $30 \mathrm{~km}$

Mw 7.3, $62 \mathrm{~km} * 21 \mathrm{~km}$

Dip 20, Depth $25 \mathrm{~km}$

Mw $6.5,5 \mathrm{~km} * 15 \mathrm{~km}$

Dip $40^{\circ}$, Depth $5 \mathrm{~km}$

Length $10 \mathrm{~km}$, Width $200 \mathrm{~m}$

Thickness $100 \mathrm{~m}$, initial depth $150 \mathrm{~m}$

Slope $15^{\circ}$

Length $5 \mathrm{~km}$, Width $200 \mathrm{~m}$

Thickness $200 \mathrm{~m}$, initial depth $250 \mathrm{~m}$

Slope $15^{\circ}$
Description

North Seram Megathrust

1950 Ambon tsunami

A normal fault earthquake onshore of Ambon Island

Subaerial landslide

Subaerial landslide

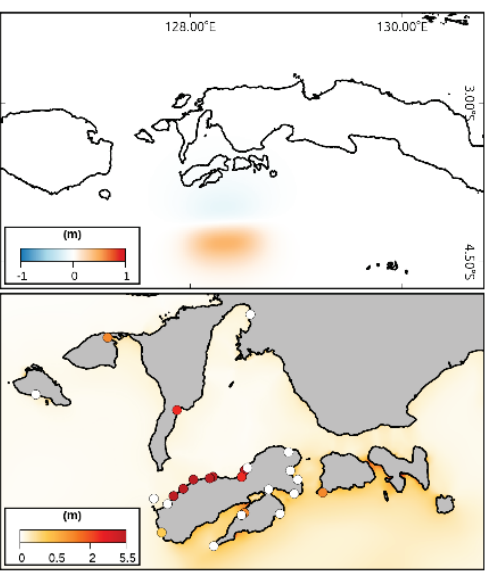

(b)

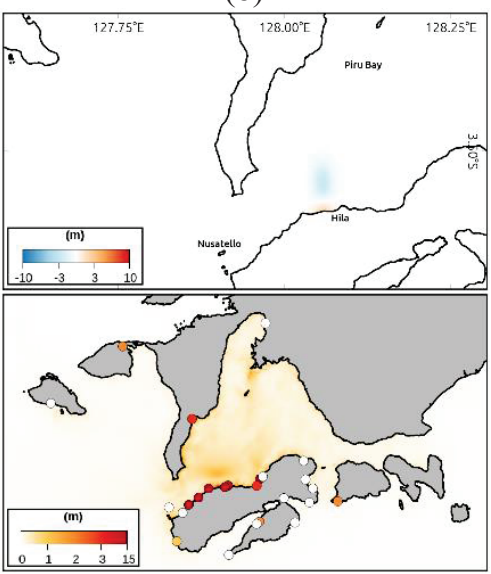

(e)

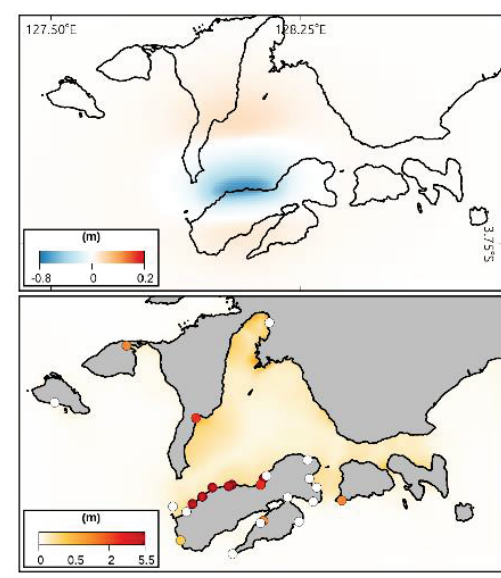

(c)

Rumphius report of tsunami height

- No information

- $<0.50 \mathrm{~m}$

- $0.50-1.00 \mathrm{~m}$

- $1.00-2.00 \mathrm{~m}$

- $2.00-5.00 \mathrm{~m}$

- $5.50-110 \mathrm{~m}$

FIGURE 1. Initial sea surface displacement (top) and maximum tsunami height around Ambon Island (bottom) for scenario a) F01, b) F02, c) F03, d) L01, e) L02. Circles colored are tsunami height reported from [1] report. Scale bar of initial sea surface displacement and maximum tsunami height between scenario (a-c) and (d-e) are different. 


\section{THE 1992 FLORES TSUNAMI}

On 12 December 1992, Flores Island was struck by an earthquake of magnitude Mw 7.8 [10]. Then it was followed by tsunami a little less than $7 \mathrm{~m}$ on the western end of the north coast to more than $10 \mathrm{~m}$ on the eastern end of the north coast, and up to $26 \mathrm{~m}$ at Riang-Kroko village [11]. The wave propagated northward and was recorded by one tide gauge at Palopo, Sulawesi as well. The event that occurred at 5:30 am GMT caused more than 1700 deaths [11].

There are several tsunami sources of this event that have been suggested [12], [13], [14]. They have a similar strike fault angle which is quite different compared to mapped locations of the Flores back-arc thrust [15] used in national seismic and tsunami hazard assessments [16], [17]. Moreover, only one source model proposed by [13] has been validated against the tsunami waveform recorded at Palopo but the model uses an amplification factor in order to match the observation data. Here we rerun a source model proposed by [14] as the latest tsunami source available of this event in order to validate the tsunami waveform at Palopo tide gauge and tsunami height on Maumere.

We extend the digital elevation model used by [14] until Palopo, Sulawesi by combining GEBCO and TCarta Marine dataset for the bathymetry and SRTM for the topography models. Then we run a tsunami model using nested grids on ANUGA and JAGURS. ANUGA is used by [14] in their DEM sensitivity study and we use this model in order to benchmark JAGURS. The domain model setup of this event can be seen in Figure 2.
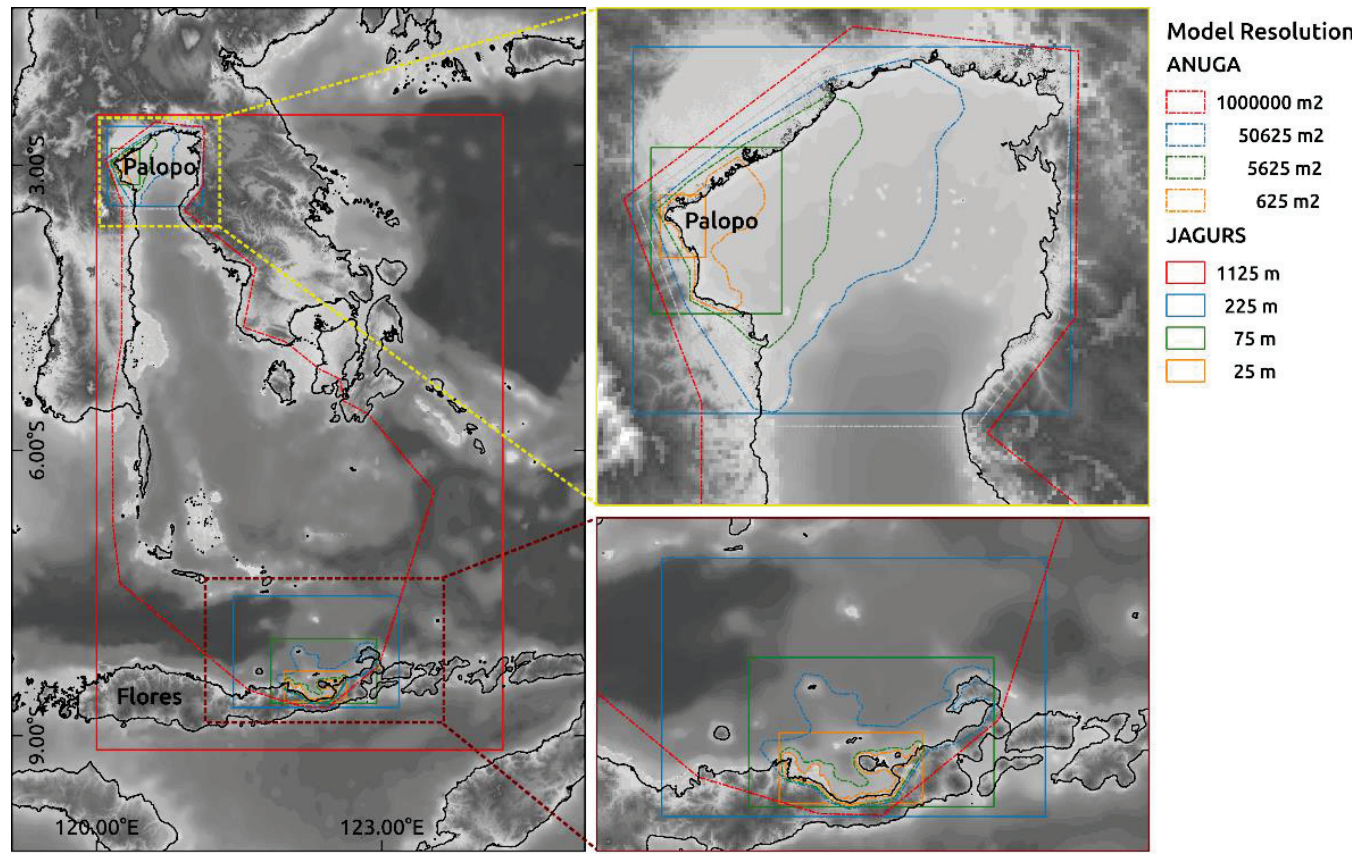

(a)

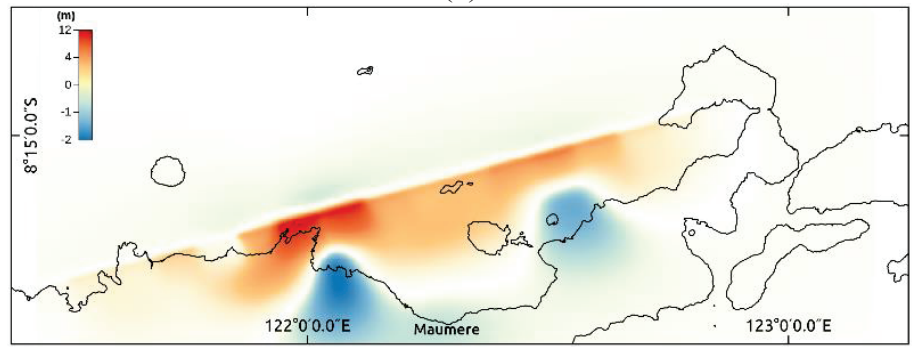

(b)

FIGURE 2. a) Domain model of the 1992 Flores tsunami on ANUGA (dashed polygons) and JAGURS (solid polygons). Color shows mesh resolution for each polygon. b) Tsunami source model proposed by [14].

In general, ANUGA and JAGURS produce similar first waveform output at Palopo tide gauge (Fig 3a) as well as maximum tsunami height on land (Fig 3b). The waveform shapes have good agreement compared to the observed tsunami waveform. The maximum tsunami height recorded was $0.25 \mathrm{~m}$ while the source model was able to generate 
a $0.22 \mathrm{~m}$ tsunami at Palopo. Furthermore, the wave time period resulted from the source model is 5 minute shorter than the observation (69 minute). However, the source model proposed by [14] arrives 10 minutes late than the data. Moreover, ANUGA and JAGURS have a different on wet/dry numerical scheme that causes the waveforms to be different after the first wave.

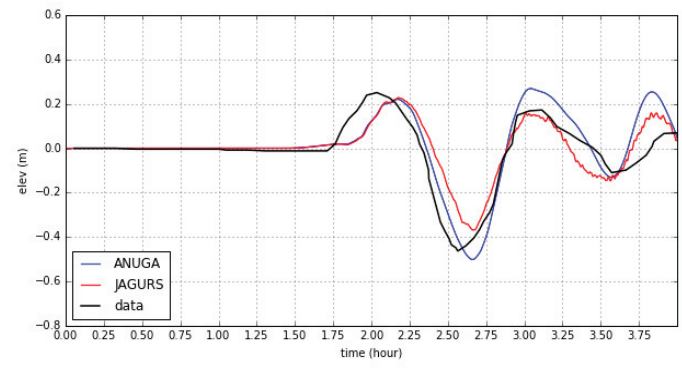

(a)

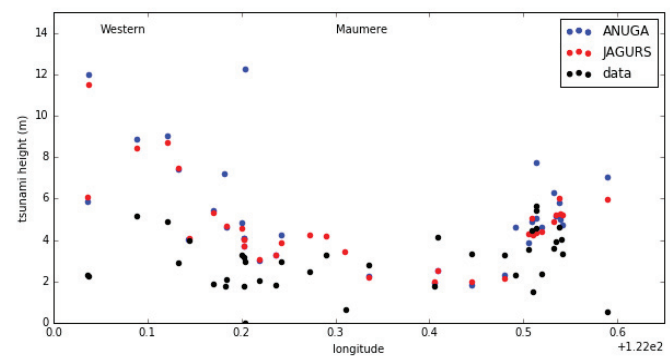

(b)

FIGURE 3. a) Waveforms at Palopo tide gauge. Data is digitized from [13]; b) Maximum tsunami height on land on Flores Island. Tsunami field survey data from [11].

Onshore, the [14] source model produces a higher tsunami on the western coast of Maumere and matches relatively well on the center to eastern side (Fig 3b). However, we do not compare the output at Riang-Kroko village since the very high tsunami here was presumable due to a landslide [10], [11], [13]. The source model that we use does not include a landslide factor.

Then we run another tsunami model using five simple homogeneous uniform slip fault models (Fig 4) in order to have a better idea how to set up a new finite source model for this event (Table 2). The 'S00' scenario is a simplification of the model proposed by [14]. It has $125 \mathrm{~km}$ length and $35 \mathrm{~km}$ width with $7.4 \mathrm{~m}$ slip and $103^{\circ}$ rake angle. Moreover, the fault dips $30^{\circ}$ to south and strikes $75^{\circ}$ from north. Then we try using a lower dip angle on 'D01' and move the epicenter northward on 'E01'. We run two models by changing the strike angle $\pm 5^{\circ}$ on 'S01' and 'S02' respectively.

TABLE 2. Simple homogeneous fault model of the 1992 Flores event

\begin{tabular}{cccccccccc}
\hline Scenario & \multicolumn{2}{c}{ Epicenter } & Strike & Rake & Dip & Depth & Slip & Length & Width \\
\hline Simple-S00 & $122.15589^{\circ} \mathrm{E}$ & $8.53848^{\circ} \mathrm{S}$ & $75^{\circ}$ & $103^{\circ}$ & $30^{\circ}$ & $11 \mathrm{Km}$ & $7.4 \mathrm{~m}$ & $125 \mathrm{Km}$ & $35 \mathrm{Km}$ \\
Simple-D01 & $122.15589^{\circ} \mathrm{E}$ & $8.53848^{\circ} \mathrm{S}$ & $75^{\circ}$ & $103^{\circ}$ & $25^{\circ}$ & $11 \mathrm{Km}$ & $7.4 \mathrm{~m}$ & $125 \mathrm{Km}$ & $35 \mathrm{Km}$ \\
Simple-E01 & $122.15589^{\circ} \mathrm{E}$ & $8.43848^{\circ} \mathrm{S}$ & $75^{\circ}$ & $103^{\circ}$ & $30^{\circ}$ & $11 \mathrm{Km}$ & $7.4 \mathrm{~m}$ & $125 \mathrm{Km}$ & $35 \mathrm{Km}$ \\
Simple-S01 & $122.15589^{\circ} \mathrm{E}$ & $8.53848^{\circ} \mathrm{S}$ & $70^{\circ}$ & $103^{\circ}$ & $30^{\circ}$ & $11 \mathrm{Km}$ & $7.4 \mathrm{~m}$ & $125 \mathrm{Km}$ & $35 \mathrm{Km}$ \\
Simple-S02 & $122.15589^{\circ} \mathrm{E}$ & $8.53848^{\circ} \mathrm{S}$ & $80^{\circ}$ & $103^{\circ}$ & $30^{\circ}$ & $11 \mathrm{Km}$ & $7.4 \mathrm{~m}$ & $125 \mathrm{Km}$ & $35 \mathrm{Km}$ \\
\hline
\end{tabular}

Overall, all of the simple models proposed are still late compared to the tsunami recorded at the Palopo tide gauge (Fig 5). Even by moving $0.1^{\circ}$ northward speeds up the waveform by only about 4 minutes and produces a higher waveform. Furthermore, changing of the strike angle by $+5^{\circ}$ increasing the waveform height on the other hand $-5^{\circ}$ producing smaller waveform compare to S00. Moreover, reducing the dip value (D01) causes the waveform to be just a little bit faster and higher compare to S00.

We conclude that the [14] source model produces a reasonable waveform but is late compare to tsunami recorded at Palopo. Moreover, this source overestimates the tsunami height on land on the western side of Maumere. Furthermore, using five simple homogeneous fault models do not change the waveform. It is also possible that the timing of the digitized waveform we use is not very accurate.

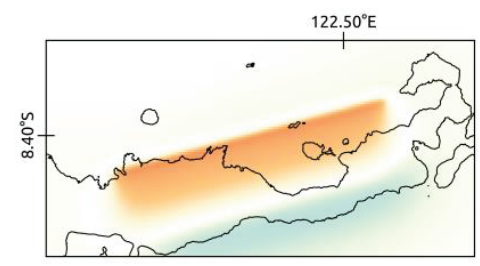

(a)

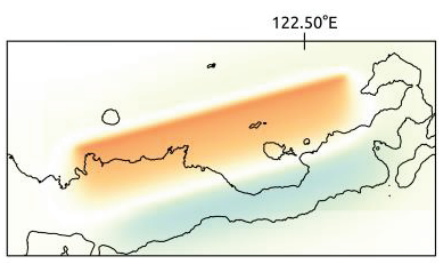

(b)

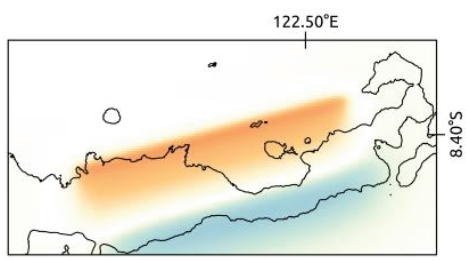

(c) 


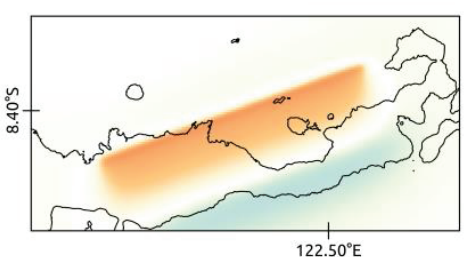

(d)

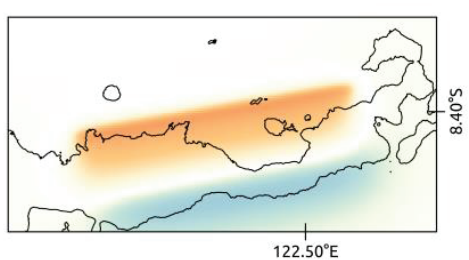

(e)

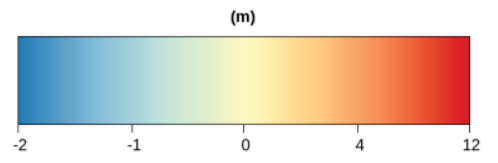

FIGURE 4. Initial sea surface displacement of a) S00 source model; b) E01; c) D01; d) S01; e) S02.

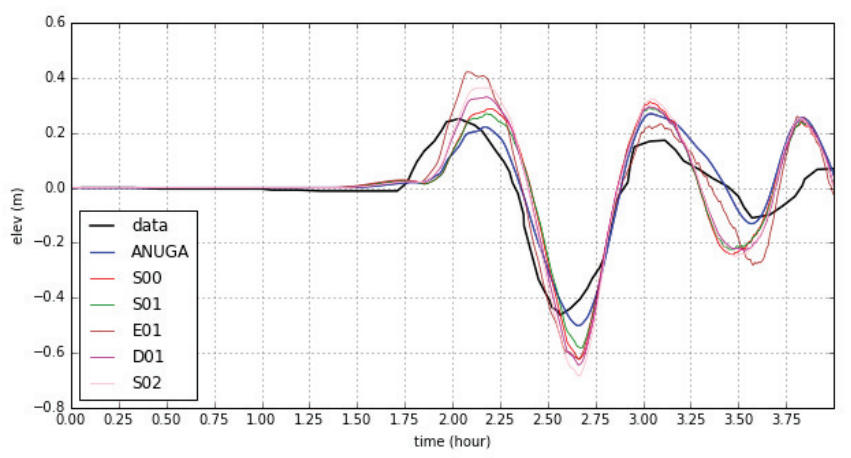

FIGURE 5. Waveforms at Palopo tide gauge from simple homogeneous fault models.

\section{CONCLUSION}

In order to have a better tsunami hazard assessment, we do need to understand how historical tsunamis were generated. We consider two studies of the 1674 Ambon and 1992 Flores tsunamis. Firstly, either a submarine landslide or a local tectonic fault on the north cost of Ambon Island is suggested as the main source of the gigantic tsunami observed along the shoreline. However, there is no detail information on this. Secondly, the [14] source model produces a good agreement of tsunami waveforms compared to tide gauge data at Palopo, Sulawesi but 10 minutes late. Moreover, it overestimates tsunami height on land western side of Maumere. By running five homogeneous fault models, we find that the waveforms are not very sensitive to the details or rupture. We note that neither of the source models proposed for these historical events are included in the source model for Indonesia's national probabilistic tsunami hazard assessment [17].

\section{ACKNOWLEDGMENT}

We thank to Dinas Hidro-Oseanografi TNI-AL for providing nautical charts surround Ambon Island and National Computer Facility under project Computational Earth Imaging (xe8) and Geohazard Modelling for the Asia-Pacific Region (n74) for providing a supercomputer facility to run these tsunami models. This research was partially funded by the Australian Department of Foreign Affairs and Trade (DFAT) through the Australian Awards Scholarship and Research School of Earth Sciences, the Australian National University's student grant. Figures were generated using Quantum GIS software and matplotlib python plotting library.

\section{REFERENCES}

1. Rumphius, G. E., "Waerachtigh verhael, van de schucklijcke aerobebing nu onlanghs eenigen tyd herwaerts, end voornaementlijck op en den 17. February des Jaers 1674 voorgevallen, in / en ontrent de Eylanden van Amboina." (W. Buijze, Trans.) Batavia: W. Buijze, 1675. 
2. National Geophysical Data Center / World Data Service (NGDC/WDS), "Global historical tsunami database", National Geophysical Data Center, doi:10.7289/V5PN93H7, 2016.

3. Latief, H., Puspito, N. T., and Imamura, F., "Tsunami catalog and zones in Indonesia," in Journal of Natural Disaster Science, 22(1), pp. 25 - 43 (2000).

4. Soloviev, S., and Go, C., "Catalogue of tsunamis on the western shore of the Pacific Ocean (173 - 1968)", (Moscow, USSR: Nauka Publishing House, 1974).

5. Baba, T., Takahashi, N., Kaneda, Y., Ando, K., Matsuoka, D., and Kato, T., "Parallel implementation of dispersive tsunami wave modelling with a nesting algorithm for the 2011 Tohoku tsunami," in Pure and Applied Geophysics. doi:10.1007/s00024-015-1049-2, 2015.

6. Watkinson, I. M., and Hall, R., "Fault systems of the eastern Indonesian triple junction: evaluation of quaternary activity and implications for seismic hazards," (P. Cummins, \& I. Meilano, Eds.) in Geohazards in Indonesia: Earth Science for Disaster Risk Reduction, 2016.

7. Brouwer, H., "Some relations of earthquakes to geologic structure in the East Indian Archipelago," in Bulletin of the Seismological Society of America, $11(3$ - 4), pp. 166 - 182 (1921).

8. Papazachos, B., Scordilis, E., Panagiotopoulus, D., Papazachos, C., and Karakaisis, G. (2004). Global relations between seismic fault parameters and moment magnitude of earthquakes. 34, 1482 - 1489.

9. Watts, P., Grilli, S. T., Tappin, D., \& Fryer, G. (2005, November/December). Tsunami generation by submarine mass failure II: predictive equations and case studies. Journal of Waterway, Port, Coastal, and Ocean Engineering, 131(6), 298 - 310. doi:10.1061/(ASCE)0733-950X(2005)

10. Yeh, H., Imamura, F., Synolakis, C., Tsuji, Y., Liu, P., \& Shi, S. (1993, August 17). The Flores Island tsunamis. Eos, Transactions, American Geophysical Union, 74(33), 369, 371 - 373.

11. Tsuji, Y., Matsutomi, H., Imamura, F., Takeo, M., Kawata, Y., Matsuyama, M., . . Harjadi, P. (1995). Damage to coastal villages due to the 1992 Flores Island earthquake tsunami. PAGEOPH, 144(3/4), 481 - 524.

12. Imamura, F., Gica, E., Takahashi, T., \& Shuto, N. (1995). Numerical simulation of the 1992 Flores tsunami: interpretation of tsunami phenomena in northeastern Flores Island and damage at Babi Island. PAGEOPH, 144(3/4), 555 - 568.

13. Hidayat, D., Barker, J. S., \& Satake, K. (1995). Modeling the seismic source and tsunami generation of the December 12, 1993 Flores Island, Indonesia, earthquake. PAGEOPH, 144(3/4), 537 - 554.

14. Griffin, J., Latief, H., Kongko, W., Harig, S., Horspool, N., Hanung, R., . . Cummins, P. (2015). An evaluation of onshore digital elevation models for modeling tsunami inundation zones. Frontiers in Earth Science, 3(32), 16. doi:10.3389/feart.2015.00032

15. Silver, E. A., Reed, D., \& McCaffrey, R. (1983). Back arc thrusting in the eastern Sunda Arc, Indonesia: A consequence of arc-continent collision. Journal of Geophysical Research, 88(B9), 7429-7448.

16. Irsyam, M., Sengara, I., Aldiamar, F., Widiyantoro, S., Triyoso, W., Natawidjaja, D. H., . . Ridwan, M. (2010). Development of seismic hazard maps of Indonesia for revision of hazard map in SNI 03-1726-2002. Bandung.

17. Horspool, N., Pranantyo, I., Griffin, J., Latief, H., Natawidjaja, D., Kongko, W., . . . Thio, H. (2014). A probablistic tsunami hazard assessment for Indonesia. Nat. Hazards Earth Syst. Sci., 14(3105), 3105-3122. doi:10.519/nhess-14-3105-2014 